\title{
Urban Prophets: Creating Graffiti as a Means of Negotiating the Constructs of Urban Public Spaces
}

\author{
Alison L. Fraser \\ Department of Cultural Studies \\ Trent University
}

\begin{abstract}
For this examination, graffiti and neo-graffiti have been compared to public art in order to reveal the ideological constructions of urban public spaces. How does graffiti interact with the construction of urban public spaces? How is graffiti similar to and different from public art? Which of these art forms better represents the public and city living? By comparing public art to (neo)graffiti in Toronto, Ontario and Los Angeles, California, the gendered, racialized, and class-based exclusions present in R. Florida's (2002) creative cities framework as theorized by authors such as N. Smith (1996), Sharon Zukin (1996), and G. Standing (2011) can be revealed. Urban public spaces are carefully shaped by those in control, the government and corporations, with the intention of creating spaces and citizens within those spaces that can be a functioning part of their neoliberal capitalist system. Graffiti and neo-graffiti act as a visual interruption to this system, which in turn can be thought of as physically represented by public art. In this way (neo)graffiti is created by a minority of citizens with the hopes of reclaiming their right to exist in urban public spaces despite layers of ideological exclusions.
\end{abstract}

\section{Keywords}

Graffiti, neo-graffiti, public art, urban public space

\section{Introduction}

The continuous presence of graffiti in the urban public sphere suggests that it is more than mere vandalism. Graffiti and its cousin neo-graffiti participate in and against the spatial politics of containment, exclusion, and appropriation that tacitly exist in the ideologies of urban public spaces (Waclawek, 2011). ${ }^{1}$ These operate at the intersection of urban development via the creative cities formula for gentrification, social organization focusing on the government's effect on the structures of labour, and artistic expressions of the graffiti subculture and public art. Graffiti and neo-graffiti artists' expressive agency functions as acts of resistance and place-making in the creative cities framework as it applies to urban public spaces. This will become clear by focusing on the contemporary examples of (neo)graffiti and public art located in Toronto, Ontario and Los Angeles, California.

\section{Literature Review: Creative Cities, Governmentality, and the Art of the City}

\section{Creative Cities}

Richard Florida formulated the creative cities framework as a model for urban development or gentrification. ${ }^{2}$ Florida suggests that if a city wants to prosper by attracting what Florida calls the creative class, it must focus on development initiatives that promote the categories of technology, talent, and tolerance-the 3 T's. ${ }^{3}$ The creative class is, essentially, types of people that desire "individuality, self-expression and openness" in their lifestyles (Florida, 2002, p. 6). Florida's theory reflects the fall and rise of city living that began in the 1950s with post-war urbanism, which sees people mov- 
ing out of the inner city and into suburbs (Zukin, 1996). In the 1980s when globalization becomes prevalent, the flow of capital, in the hands of the elite, returns to the derelict city, which was viewed as a substantial investment opportunity. The investment of capital and the shaping of the city into the creative city, through the process of gentrification, is the revanchist city (Smith, 1996). In the revanchist city, the foundations for excluding certain types of people are laid through "a race/class/gender terror felt by middle- and ruling-class whites who are suddenly stuck in place by a ravaged property market...and the emergence of minority and immigrant groups" (Smith, 1996, p. 211). Cities also currently compete with each other in a neoliberal, globalized capitalist paradigm using the cheapest forms of labour to create capital and enhance their own image in what can be understood as the global city (Forkert, 2011).4 The global city desires art contained within the system, according to Sharon Zukin (1996), which plays a direct role in a city's perceived economic growth; art and economics are intrinsically linked within the global city. ${ }^{5}$ In the revanchist city, which is trying to become a global city, if a (neo)graffiti artist is caught making art outside of the official system, they face stiff penalties including fines, jail time, and community service ("Penal Code," n.d.; "Graffiti Management," 2015). When the neoliberal capitalist system cannot contain graffiti, it will erase it (Stewart, 1987). ${ }^{6}$ Zukin (1996) observed that architecture, as a part of urban planning and zoning laws, contains within its structural forms social constraints to which the public conform. ${ }^{7}$ Therefore, it is natural for those in power to want to exclude graffiti from urban architectural facades as it interrupts and offers new interpretations of the city and ways for the public to move through the city. In the global revanchist city, the creative city framework that is used to make the city appear attractive actually reinforces exclusionary practices that do not tolerate any perceived threats of difference that might scare away potential investments of neoliberal capital (Zukin, 1996).

\section{Governmentality}

Urban public spaces are complex entities of exclusion and inclusion guided by $18^{\text {th }}$ century Enlightenment rational thinking, which has influenced modern forms of governmentality (Miles, 1997). There is a process of imposing values and norms onto citizens that unconsciously work on the body to enforce desirable qualities in citizens while rejecting undesirable qualities in the creation of the ideologies of exclusion. The government controls what can be placed into public spaces, such as art, regulates architecture, and determines who can use public spaces; this normalizes and dematerializes the ideologies of exclusion. The precariat, which is arguably a category-cum-social class that most artists fall into nowadays, experiences the ideologies of exclusion. To Guy Standing (2011), society views the precariat as a "detached group of socially ill misfits living off the dregs of society" (p. 8). The precariat becomes stuck in this existence because of limited social mobility due to the precarious nature of their labour (Standing, 2011). Through ideological containment, the government seeks to replicate the precariat class - of which (neo)graffiti artists are a part-through criminalization and self-surveillance based on social norms (Standing, 2011). Those that influence the government, reinforce social norms, and create the ideologies of exclusions are the moral entrepreneurs. Jeff Ferrell (1993) defines the moral entrepreneurs as:

Capitalism and the state, the church and the school, [which] all claim definitive understanding of the world; strive to define for their subordinates the boundaries of perception and appreciation; and in this way share in the spoils of epistemic authority (p. 161).

Furthermore, the moral entrepreneurs create the dominant aesthetic for the city that plays out in urban public spaces referred to as the hegemony of style (Ferrell, 1993). To the moral entrepreneurs, the cleanliness of the city's architecture and public art conforming to the hegemony of style is synonymous with authority and control (Ferrell, 1993). Governments also want advertising in 
urban public spaces because it makes orderly and clean cities through the addition of glossy images that promote desirable consuming bodies, i.e., people that can fully participate in capitalist society (Flood, 2012). Neoliberal governmentality promotes business over the welfare of citizens in the creation of its global city image (Dickinson, 2008). As governments privatize once-public spaces by selling them to private businesses in the revanchist city, the precariat must fight for their existence in the city, and they use graffiti in this fight (Dickinson, 2008).

\section{The Art of the City}

From its inception in ca. 1960, the creation of vernacular graffiti images revolved around a subculture. Senior members of the graffiti subculture, referred to as kings, would pass down skills and techniques they had learned to novices (Latchmann, 1988). In doing so, graffiti artists kept the production of artistic knowledge something that could only be accessed by someone in the subculture ("The Words," n.d.). In the 1990s, neo-graffiti breaks from the graffiti subculture model with the movement of artist into the graffiti world using all kinds of media to create all kinds of images influenced by a fine arts aesthetic. ${ }^{8}$ Not only are (neo)graffiti artists keen observers of the urban spaces in which they live, they learn to understand these spaces in terms of visual resistance (Reiss, 2008). They can then apply their desire for disruption by using and corrupting the signs and symbols of the moral entrepreneurs (Waclawek, 2011). This is specifically applicable to brandalism-and other methods of culture jamming - and billboard tagging (Banksy, 2005). ${ }^{9}$ By its anti-authoritarian nature, (neo)graffiti is not exclusionary; it does not preclude anyone based on race, class, or gender. But, females participate less in (neo)graffiti because of the greater ideological exclusions the female gender faces in urban public spaces. ${ }^{10}$ Inhabiting the same urban public spaces, public art is art that is sanctioned by the government or a private business, i.e., the moral entrepreneurs, for an exterior or interior location that is considered to be for public use (Goldstein, 2005). Public art can be monuments and civil depictions of historic events; art-in-public-places, which are large-scale, abstract modern sculptures; art-as-public-spaces, which are benches and environmental landscapes designed to humanize the city; or the more socially minded New Genre public art (Kwon, 2004). ${ }^{11}$ Public art in any of the previously mentioned categories can be site-specific. This concept refers to public art that has been made specifically for a location (Kwon, 2004). All public art is influenced by the context of its creation and its physical location. This is important because public art can produce conflict amongst the public. These conflicts reveal the underlying histories and ideologies present in a specific place and time period.

\section{Case Studies: Graffiti, Neo-Graffiti, and Public Art in Toronto and Los Angeles}

In order to maintain a contemporary examination, only examples of graffiti, neo-graffiti, and public art made in the 2000s will be used. This temporal window demonstrates the mobilization of (neo)graffiti in the context of the neoliberalization of urban public spaces in the discourse of the creative city. As well, Toronto and Los Angeles have been chosen because both are well represented by existing literature, and both cities represent two distinct forms of urban development and (neo)graffiti practice. These case studies can reveal the ideologies of exclusion manifested in public art and the ways (neo)graffiti artists negotiate these constructions. ${ }^{12}$

\section{Graffiti, Neo-Graffiti, and Public Art in Toronto}

By the 1990s, graffiti and neo-graffiti in Toronto are widespread and established art forms (Spence, 1997). In Toronto, small groups of people participating in the graffiti subculture exist alongside of individuals and collectives creating neo-graffiti. ${ }^{13}$ The different parts of the city, such as Kensington market and Queen Street West neighbourhoods, are now covered in an array of (neo)graffiti. Addi- 
tionally, the city has commissioned many public art projects ("Public Art," 2015). Toronto is a revanchist city that uses the creative city framework, as seen through the addition of art hubs into once working class neighbourhoods, to ultimately be seen as a global city. ${ }^{14}$ One of the most notable examples of redevelopment and gentrification is the Toronto Eaton Centre (Smith, 1996). As part of these private/public constructions, there is a city by-law that dictates one percent of a building's construction budget must be spent on public art (UrbanToronto.ca, 2012). Toronto has also developed the Graffiti Management Plan, which co-opts (neo)graffiti back into the discourses of public art through offering grants to artists. The Graffiti Management Plan funds and promotes "street art" to "revitalize and engage communities" ("Graffiti Management," 2015, para. 2).

Creating both graffiti and neo-graffiti in Toronto is the infamous Spud. He is well known for his large pieces consisting of his name in hard-to-reach but visible areas of the city.

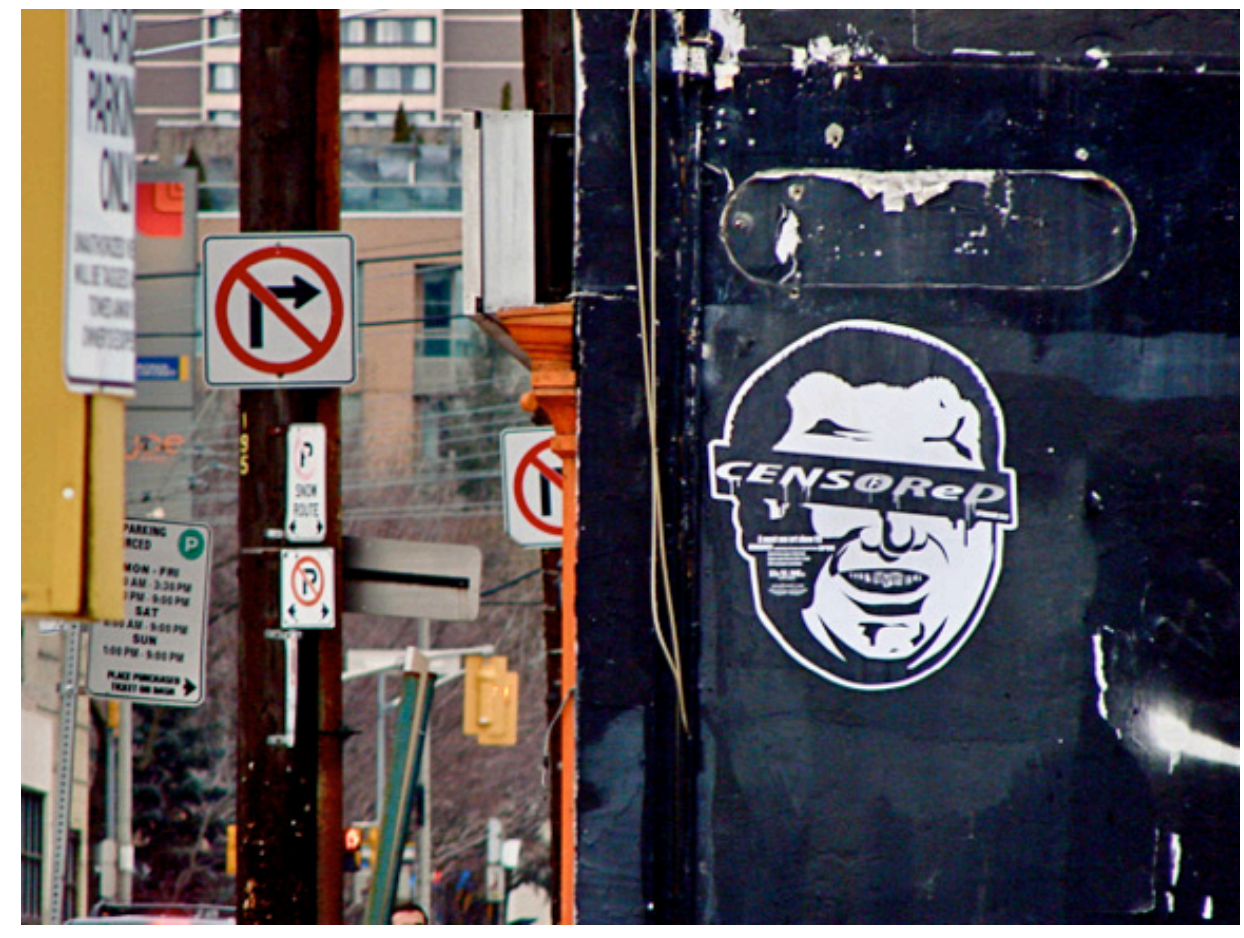

Figure 1. Rob Ford Head with Censored Bar. (Source: http://www.blogto.com)

One of his most notorious artworks is a sticker of Rob Ford's face created in reaction to the former mayor's unpopular crackdown on graffiti (Figure 1). Spud put up stickers of Ford's face all over the city (blogT0, 2012). As Spud said in an interview with CBC, "I'm stabbing him with little needles here and there, little art pieces around the city...I'll keep doing his face until he's out of office" (Rieti, 2013, para. 5). This act of open rebellion against the local government caused some of Spud's largescale artworks to be removed by the city (blogT0, 2012). It is clear, though, that (neo)graffiti artists are socially conscious and struggle against what the moral entrepreneurs consider to be appropriate uses of urban public spaces. Spud and Ford are an example of the back and forth dialogue between (neo)graffiti artists and the authority of the moral entrepreneurs in the struggle for control of the city based on its appearance. The moral entrepreneurs desire a city to be neat, tidy, and only represented by sanctioned public art while (neo)graffiti artists use urban public spaces to express their own desires and experiences. 


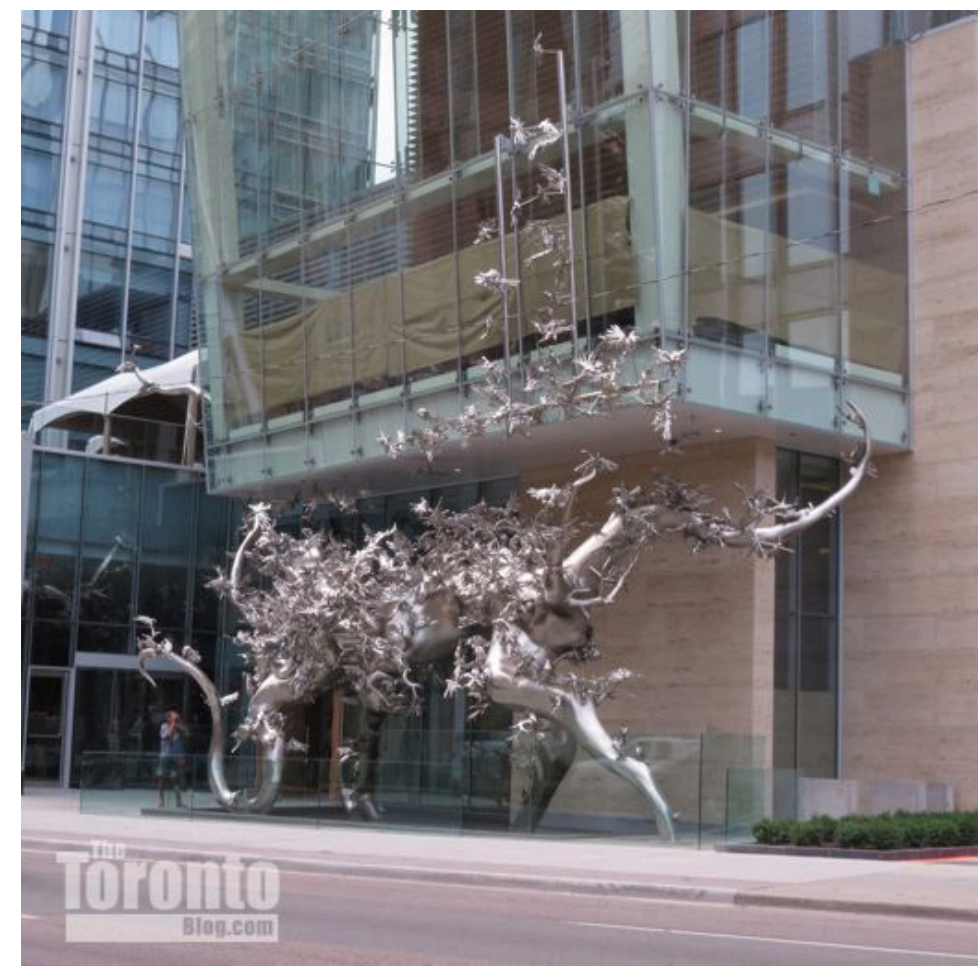

Figure 2. Zhang Huan, Rising (Source: http://thetorontoblog.com).

An example of Toronto public art is from Rising (Figure 2) created by Zhang Huan for the new luxury hotel Shangri-La Toronto on University Avenue and Adelaide Street West. The \$5 million site-specific artwork consists of countless doves rising up the building and a branch in the shape of a dragon (UrbanToronto.ca, 2012). It is meant to represent the harmony Zhang thinks humans and nature can achieve in our cities (Zhang, n.d.). The metal forms sit over top of a reflecting pool that is surrounded by a glass screen. This makes the artwork feel as if it has been taken out of the gallery and placed on the sidewalk. This is not surprising seeing as Rising was developed through a partnership between the hotel's property developers and the Art Gallery of Ontario (Zhang, n.d.). The artwork was not met with any controversy and was generally well received. It is an excellent example of the kinds of public artworks that are commissioned within the private/public relationship with private businesses placing their artworks on public sidewalks. Rising conforms to the moral entrepreneurs' hegemony of style, and their desire for the urban public sphere to have traditional fine art that allows Toronto to fit into the global city image.

Public art in Toronto is more complicit than (neo)graffiti in shaping the physical and ideological structures of the city to the tastes of the moral entrepreneur. Toronto is interesting in that it actively seeks to recruit (neo)graffiti artists into the realm of public art through grant programs. However, as Spud demonstrates, money is not always enough of a draw for a (neo)graffiti artist to enter the official system. This aligns with Anindya Raychaudhuri's (2010) idea that "by actively seeking new spaces for, and forms of art...graffiti-artists are attempting to posit their own version of the infrastructure surrounding mainstream art, which is a world they feel themselves alienated from" (p. 51). Alienation, as felt by the (neo)graffiti precariat, is a powerful force that inspires the anonymous rebellion that is (neo)graffiti. It is also important that this rebellion takes place on the streets, which, Tim Cresswell (1998) theorized, is the place where deviance is expected. The very public nature of the street is more unpredictable than our private homes and, therefore, an active site of transgression (McQuire, 2008). In Toronto in particular, there is a trend towards the privatization 
of urban public spaces as represented by the Shangri-La Toronto and the commissioning of whatever public art the property developers desired. Privatization is particularly noticeable with the appearance of all the advertisements sanctioned by the moral entrepreneurs that visually dominate urban public spaces. Advertisements help keep capital flowing and the global city image secure. Yet the presence of graffiti suggests not everyone can partake, or is happy to partake, in this system. Anne Cronin (2006) argued, "because both advertising and graffiti punctuate people's everyday experiences and create an urban vernacular, these forms nevertheless articulate an embeddedness of place and experience alongside a diffuse sense of a possible "elsewhere" (p. 10). "Elsewhere" is the idea that a space can exist "outside" or separate from "hegemonic knowledge" that exists within the framework of hegemonic knowledges (Cronin, 2006, p. 7). This demonstrates the paradoxical nature of urban public spaces. If elsewhere exists on the predication that there is the known, then graffiti works against the established boundaries of the known city to propose to the average person that the unknown, or elsewhere, can exist. As exemplified by Spud, elsewhere can be linked to undermining the people in and the forms of control that rule the city.

\section{Graffiti, Neo-Graffiti, and Public Art in Los Angeles}

The history of graffiti in Los Angeles began in the 1950s as gang territory markers for Cholo gangs (Deitch, Gastman, \& Rose, 2011). They appropriated the gothic font of the Los Angeles Times masthead for their graffiti (Deitch, Gastman, \& Rose, 2011). This creates a bold statement of appropriation by those that feel excluded by the city. By the 1980s, the graffiti subculture had established itself and was using a unique, chunky, geometric font for the images that artists invented (Deitch, Gastman, \& Rose, 2011). Also unique to the Los Angeles graffiti subculture is the use of heavens. These are high up, hard to reach places like freeway over passes, water towers, and billboards (Edlin, 2011). Heavens were the way Los Angeles graffiti artists adapted to their urban environment in order to be seen. A cleaning crew is not going to remove an artwork on a heaven as quickly, and a (neo)graffiti artist that takes the risk climbing up to a heaven will receive respect from their peers for putting their artwork on a prestigious spot. In Los Angeles, graffiti and neo-graffiti artists are reacting against what they call a "deeply superficial city" that struggles with racism and a gang problem (Reiss, 2008).

A good example of a Los Angeles graffiti artist is female graffiti artist Jel. She is a graffiti artist that learned this art form by participating in a subculture.

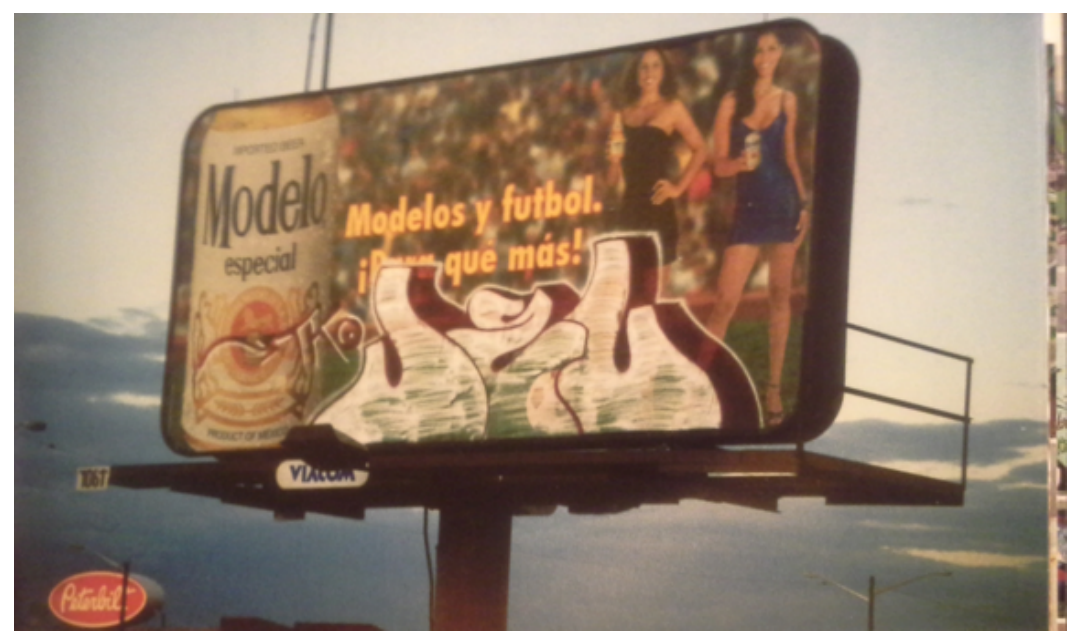

Figure 3. Jel, Throw-up (Source: Ganz, 2006) 
For example, Jel has put her artwork on billboards, which the graffiti subculture taught her to see as heavens (Figure 3). The life of a Los Angeles (neo)graffiti artist is part test of physical endurance and part artistic performance in reclaiming and altering the spaces of the city. Jel's artwork on the billboard prevents the advertisement from working and, in turn, denies Los Angele's desire for promoting capitalism and being a global city. Jel does not care about participating in the construction of the global city, which contains within it ideologies of exclusion. In particular, Jel has experienced the gendered nature of the ideologies of exclusion she has faced as a graffiti artist:

I think it takes a lot of heart for a female to go out at night to catch a spot alone. Guys only have to worry about getting arrested, jacked or killed. We have to worry about all that, plus more-like getting kidnapped or raped (Ganz, 2006, p. 65).

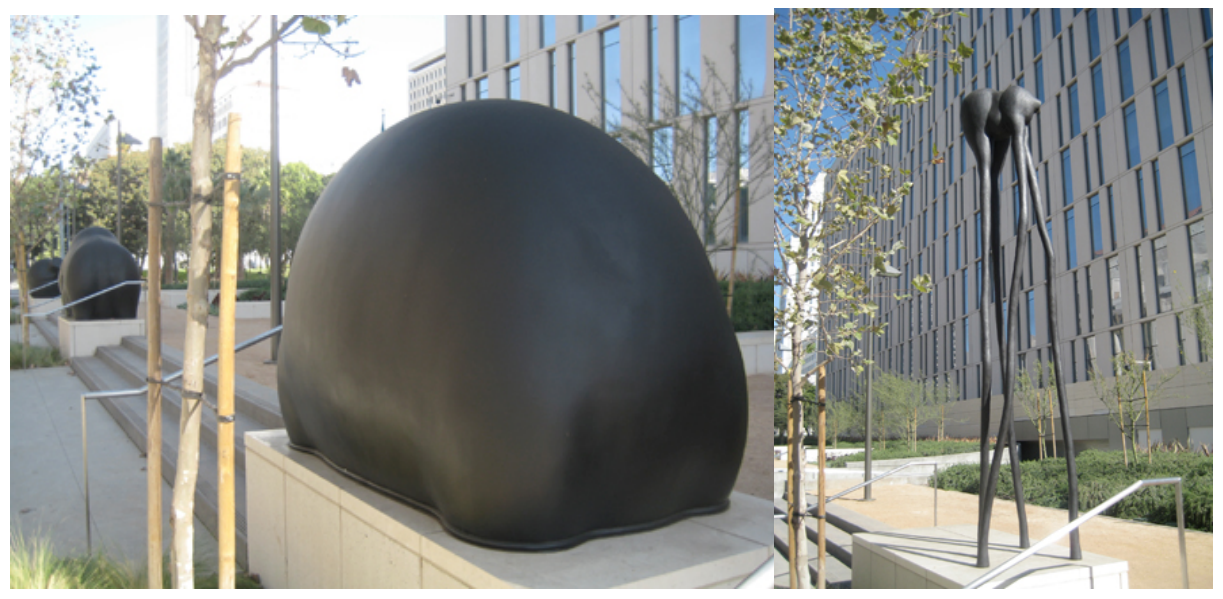

Figure 4. Peter Shelton, sixbeaststwomonkeys (Source: http://www.publicartinla.com).

A contemporary example of public art in Los Angeles is Peter Shelton's sixbeaststwomonkeys (Figure 4) (Knight, 2009). The abstract artwork is located outside of the Los Angeles Police Department, which is an area undergoing redevelopment as a part of the Community Redevelopment Agency's Central Business Redevelopment Project ("Public Art in Downtown," 1999). Behind sixbeaststwomonkeys' abstract forms are the ideologies of exclusion that are present in urban spaces and heightened during gentrification. The artwork conforms to the moral entrepreneurs' dominant fine art, non-threatening aesthetics, and it works as a small part of a larger set of policies that seek to promote business and attract financial investment into the city; public art, such as sixbeaststwomonkeys, helps to make Los Angeles a global city. Because public art is always subjected to a juried selection process, these ideologies become a part of the artwork from its conception to its execution (Goldstein, 2005). In the case of most public artworks, like sixbeaststwomonkeys, they seek to address their environment, i.e., be site-specific; however, they are denied any real possibility for negotiation or critique of the ideologies of exclusion because of the ways in which they are bound by these ideologies in their creation. It is in this regard that (neo)graffiti may represent a more public form of art because it is done by people attempting to negotiate and, ultimately, work against the ideologies of exclusion present in urban public spaces.

As Los Angeles (re)develops as a part of the revanchist city, the binary modes of thought that inform the ideological basis for our uses of urban public spaces are intensified. This divide is even more apparent in the private/public binary. With more closed circuit television (CCTV) cameras, the surveillance of public spaces encourages people to conform to private interests as they move through urban public spaces (Bottomley \& Moore, 2007). Public space is no longer for the public but instead is redeveloped for a desirable and consuming body. This also encourages fear of the 
non-consuming body-which graffiti artists are understood to have-as is evident in a statement made by the head of the police gang control unit in Los Angeles: "Graffiti decreases property value and signed buildings on block after block convey the impression that the city government has lost control, that the neighbourhood is...sliding toward anarchy" (Stewart, 1987, p. 168). Yet this desire for control just emphasizes that the spaces of the city are, as Cronin (2006) said, "contested, multiple and paradoxical" (p. 14). In seeking to construct bodies that consume, the moral entrepreneurs use both advertising and public art in urban public spaces to maintain visual supremacy over the public in the name of financial success. But, this denies the every-day experiences of the citizens within the city more and more of whom are the precariat. The city for them is different, unaccepting, and derelict; they do not possess a body that can consume and, thus, face the ideologies of exclusion. The precariat's city exists simultaneously with the clean, accepting, global revanchist city of the moral entrepreneur, which tacitly possess all the exclusions determined by class, race, and gender that are part of the ideologies of exclusion. This paradoxical city is (re)claimed by (neo)graffiti artists. ${ }^{15}$ This sentiment is summed up by Los Angeles (neo)graffiti artist Saber: "Graffiti flourishes where it's the worst. Dilapidated people out there that need someone to pray for them...Life is a dark place that's beautiful in the same token" (Pray, 2005). It is in the beautiful, ugly contradiction of paradoxical urban public spaces where graffiti flourishes and public art exists. ${ }^{16}$ As such, Los Angeles remains a contested site where the spaces of the city are being (re)developed to fit the needs of the global city's desire for consuming bodies while (neo)graffiti visually protests the ideologies of exclusion present within gentrification.

\section{Conclusion: Urban Prophets}

Despite the idealistic nature of Florida's creative city, and its drive to build a diverse community with a strong arts culture, there is still favouritism within this dialogue. As the examination of graffiti, neo-graffiti, and public art reveals, some art forms and citizens are acceptable in urban public spaces while others are not. The distinctions made by the moral entrepreneurs between desirable consuming bodies and undesirable non-consuming bodies become heightened during gentrification. It is clear that graffiti and neo-graffiti artists are not part of the perfect, gentrified global citywhich is touted as being beneficial to the public in its attraction of capital and financial investment-unless their artwork has been controlled or consumed. In the global city's formation of the creative city, there is no room for a heterogeneous public, especially, if that public contains nonconsuming bodies. It is significant that graffiti and neo-graffiti continue to exist in urban public spaces despite being policed and excluded. Graffiti and neo-graffiti can more accurately represent the diversity that exists within the public and the realities of the precariat who struggle with identity markers, such as class, race, gender, and labour. This artwork forces a dialogue onto the architectural surfaces of the city and makes the ideologies of exclusion visible. To understand (neo)graffiti as the process that creates disorder in the city is limiting. Graffiti is a visual indication of disorder not its cause. It is perhaps Banksy who best summarizes the condition of the contemporary city:

Imagine a city where graffiti wasn't illegal...[w]here every street was awash with a million colours and little phrases. Where standing at a bus stop was never boring. A city that felt like a part where everyone was invited, not just the estate agents and the barons of big business. Imagine a city like that and stop leaning against the wall-it's wet (Banksy, 2005, p. 97).

Graffiti and neo-graffiti artists' illegal art seems to allow for creative expression that can negotiate the ideological exclusions of an otherwise gentrified, anonymous city. 


\section{Notes}

1. Modern graffiti first appears in Philadelphia ca. 1960 and can be identified via its focus on vernacular images, sometimes accompanied by figures, usually produced with paint, spray paint, or markers. In the 1990s, graffiti turns into an art movement known as neo-graffiti through the incorporation of more pictorial imagery and a greater concern for traditional aesthetics using all kinds of media, such as collage and stencils. The division between graffiti and neo-graffiti is blurry at best. I will employ the term neo-graffiti instead of Street Art or post-graffiti. Although street art is the most commonly used term in published sources, graffiti and neograffiti artists do not commonly use either street art or post-graffiti; they just refer to their artwork as art. The public and the criminal codes that deal with vandalism only use "graffiti" to refer to both graffiti and neograffiti.

2. Florida's work has been widely critiqued since its original publication in 2002; however, the theories put forth remain popular and are part of the discourse surrounding (neo)graffiti. For a critique on Florida's work see J. Peck (2005) "Struggling with the Creative Class."

3. In short, technology is the creation of industry and knowledge; talent is the human factor, i.e., human capital and the ability to possess creative or cultural capital; and tolerance is the fostering of openness and diversity in the city.

4. Part of the global city discourse describes the never-ending desire for cities to present an air of success and attract the investments of businesses, tourists, and upper class citizens; anyone or anything considered outside of desirable categories is marginalized through ideological exclusions.

5. Graffiti and neo-graffiti artists are not traditionally part of the discourse on artists' involvement in the process of gentrification because they are not considered to be art. The only notable exception to this is Bansky whose artwork can raise real estate prices according to Wall and Piece (2005). For more on the complicated process of how artists are involved in gentrification by moving to a cheap, edgy part of a city and slowing making it an attractive site before being excluded from that area see R. Deutsche and C. G. Ryan (1984) "The Fine Art of Gentrification."

6. Unlike public art, graffiti and neo-graffiti artists are not considered to be artists and are not part of Florida's 3 T's model. This is likely because their creativity is not a willing participant in neoliberal capitalist systems and, thus, illegal.

7. A famous example of city planning and architecture placing constraints on the public is G. Haussmann's reconstruction of 19th century Paris, France.

8. Older practitioners of graffiti who have made the move into neo-graffiti exist as a bridge between the two. Notable examples of this are Eine and Banksy.

9. Brandalism and culture jamming are similar in that both art forms consist of the artist altering the signs and symbols of advertising and putting the corrupted symbols back out into the public, usually, to make a political statement. Brandalism specifically involves the altering of brand logos and trademarks.

10. Although there are more female artists participating in neo-graffiti than graffiti, they are still the minority. More research must be conducted on the exclusionary practices and ideologies of the city and Euro-American forms of gender oppression that still limit a woman's full participation in subcultures. For more on the ideological exclusions that groups of people can face in public spaces see M. Miles (2007) Art, Space and the City: Public Art and Urban Futures.

11. New Genre public art consists of artists working outside of the gallery and commercial art world to create artwork that addresses a specific social problem and promotes beneficial changes. For more on new genre public art, or public art in general, see M. Kwon (2004) One Place After Another: Site-Specific Art and Locational Identity.

12. While only one example of (neo)graffiti and public art from Toronto and Los Angeles will be examined, they are representative of their cities. More examples of graffiti are easily obtainable from an Internet search while examples of public art are harder to find and may involve visiting the city.

13. American cities, like Philadelphia, Los Angeles, and New York are exceptional in that they have a long history of graffiti and graffiti subcultures. This is likely due to the intense ideological exclusions people face in their daily lives in those cities. While these ideologies of exclusion are still present in Canadian cities, Canadian graffiti subcultures exist on a smaller scale without the same kind of historical legacy.

14. These art hubs are part of larger gentrification campaigns to specifically attract the creative class. A controversial art hub is the one created in the Queen Street West neighborhood. 
15. Although this is set up as a binary comparison, in reality there are many spaces of the city based on our personal experiences that exist in tandem with each other. These spaces are subjective and will be experienced differently by each individual within Euro-American society. Binary constructions are useful but must always be held in check.

16. For all that, it should be mentioned that both art forms contain paradoxes within themselves: (neo)graffiti can address the lived racial, sexist, and classist exclusions faced by the artist in urban spaces; however, public art is better at communicating a positive message to public viewers when such a message is included. But the personal experiences behind (neo)graffiti art are not communicated to the public most of whom would rather have permanent, inaccessible, and abstract artworks installed in their city spaces because the moral entrepreneurs have convinced the public they know what is appropriate for those spaces.

\section{References}

Banksy. (2005). Wall and piece. London, UK: Century.

BlogTo. (2012, August 10). 10 Toronto graffiti writers worth knowing about [Web long comment]. Retrieved from: http://www.blogto.com

Bottomley, A., \& Moore, N. (2007). From walls to membranes: Fortress polis and the governance of urban public space in 21st century Britain. Law Critique 18, 171-206.

Cresswell, T. (1998). Night discourse: Producing/consuming meaning on the street. In N. R. Fry (Ed.), Images of the street: Planning, identity and control in public space (pp. 268279). New York, NY: Routledge.

Cronin, A. M. (2011). Urban space and entrepreneurial property relation: Resistance and the vernacular of outdoor advertising and graffiti. Retrieved from http://www.comp.lancs.ac.uk/

Deitch, J., Gastman, R., \& Rose, A. (2011). Art in the streets. New York, NY: Skira Rizzoli.

Dickinson, M. (2008). The making of space, race and place: New York City's war on graffiti, 1970 to the present. Critique of Anthropology 28, 27-45.

Edlin, J. (2011). Graffiti 365. New York, NY: Abrams.

Ferrell, J. (1993). Crimes of style: Urban graffiti and the politics of criminality. New York, NY: Garland.

Flood, C. (2012). British posters: Advertising, art and activism. London, UK: V\&A Publishing.

Florida, R. (2002). The rise of the creative class and how it's transforming work, leisure, community and everyday life. New York, NY: Basic Books.

Florida, R. (2005). Cities and the creative class. New York, NY: Routledge.

Forkert, K. (2011). Bread and five-ring circuses: Art, activism, and the Olympic games in Vancouver and London. In J. Keri Cronin \& K. Robertson (Eds.), Imagining resistance: Visual culture and activism in Canada (pp. 147-163). Waterloo, Ontario: Wilfrid Laurier University Press.

Ganz, N. (2006). Graffiti women: Street art from five continents. New York, NY: Abrams.

Goldstein, B. (Ed.). (2005). Public art by the book. Seattle, Washington: University of Washington Press.

Graffiti management plan. (2015). Retrieved from http://www.toronto.ca/

Knight, C. (2009, October 22). Public art review: Peter Shelton's sixbeaststwomonkeys

[Web long comment]. Retrieved from http://latimesblogs.latimes.com/

Miwon K. (2004). One place after another: Site-specific art and locational identity. Cambridge, MA: The MIT Press. 
Lachmann, R. (1988). Graffiti as career and ideology. American Journal of Sociology 94(2), 229-250.

McQuire, S. (2008). The media city: Media, architecture and urban space. London, UK: Sage Publications.

Malcolm, M. (1997). Art, space and the city: Public art and urban futures. London, UK: Routledge.

Penal code section 594-625c. (n.d.). Retrieved from http://www.leginfo.ca.gov/ Pray, D. (Director). (2005). Infamy [Motion picture]. USA: Image Entertainment.

Public art. (2015). Retrieved from http://www.toronto.ca/

Public art in downtown Los Angeles. (1999, February). Retrieved from http://www.publicartinla.com/

Raychaudhuri, A. (2010). Just as good a place to publish: Banksy, graffiti and the textualisation of the wall. Rupkatha Journal on Interdisciplinary Studies in Humanities 2(1), 50-58.

Reiss, J. (Director). (2008). Bomb it [Motion picture]. USA: Antidote Films/Flying Cow Productions.

Rieti, J. (2013, June 14). Toronto graffiti artist rips Rob Ford amid crack scandal. CBC News. Retrieved from http://www.cbc.ca/

Smith, N. (1996). The new urban frontier: Gentrification and the revanchist city. London, UK: Routledge.

Spence, A. (1997). Tags \& pieces: A photo collection of Canadian graffiti art. Toronto, Ontario: Haspence.

Standing, G. (2011). The precariat: The new dangerous class. London, UK: Bloomsbury.

Stewart, S. (1987). Ceci tuera cela: Graffiti as crime and art. In J. Fekete (ed.), Life after postmodernism: Essays on value and culture (pp. 161-180). London, UK: Macmillan.

The words: A graffiti glossary. (n.d.). Retrieved from http://www.graffiti.org/

UrbanToronto.ca. (2012, May 6). Zhang Huan's astounding 'Rising' unveiled at living Shangri-La [Web long comment]. Retrieved from http://urbantoronto.ca

Waclawek, A. (2011). Graffiti and street art. New York, NY: Thames \& Hudson.

Zhang, H. (n.d.). Rising. Retrieved from http://www.zhanghuan.com/

Zukin, S. (1996). Space and symbols in an age of decline. In A. D. King (Ed.), Re-presenting the city: Ethnicity, capital and culture in the 21st-century metropolis (43-59). Basingstoke, UK: Macmillan 